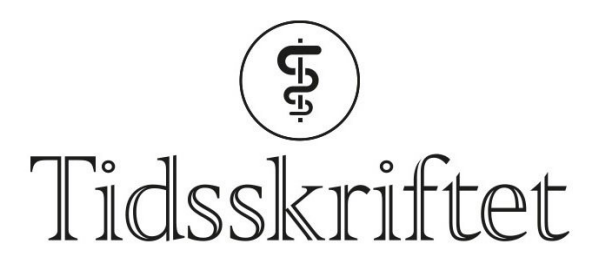

DEN NORSKE LEGEFORENING

\title{
Kari Nissen Fuglseth
}

MINNEORD

GYRID GYLSETH

RUTH LANGHOLM

KIRSTI LØKEN

INGER HELENE VANDVIK

KAREN HELENE ØRSTAVIK

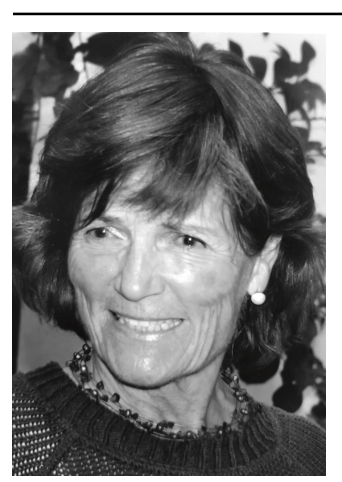

Vår kjære kullkamerat og gode venninne Kari Nissen Fuglseth døde 4. oktober etter noe tids sykdom. Hun ble 78 år gammel.

Kari vokste opp på Odnes og var knapt 13 år gammel da hun og tvillingsøster Lise reiste til Oslo for å gå på realskolen og deretter gymnasiet på Hegdehaugen skole. Hun begynte på medisinstudiet i Oslo i 1958 før hun hadde fylt 18 år. Etter turnustjeneste på Lovisenberg sykehus og i Askim begynte hun i allmennpraksis, og hun arbeidet på samme legekontor i Lørenskog fra 1966 til 2007. Kari var glad i jobben sin og holdt seg godt oppdatert ved kurs og faglige møter. Takknemlige pasienter tok initiativ til at hun skulle få Kongens Fortjenstmedalje, siden hun hadde oppfylt allmennpraktikernes ideal om å være «kontinuerlig, omfattende, personlig og forpliktende».

Det var ikke bare pasientene som satte pris på Kari. Gjennom hele livet hadde hun en helt spesiell evne til å knytte varige vennskap. Kari hadde stor livsglede og godt humør. Hun var aktiv, engasjert, positiv, alltid lyttende og med stor omtanke for andre.

En øyesykdom gjorde pensjonisthverdagen vanskeligere for Kari. Men takket være hennes pågangsmot og samboer Pers omsorg kunne hun fortsette å leve sitt aktive liv. Da Kari fikk en alvorlig kreftdiagnose, og Per døde noen uker senere, viste hun sin styrke. Hun tok 
styringen av det praktiske og fortsatte å møte oss med samme varme og oppmerksomhet som hun alltid hadde vist oss. Hennes mot i møte med sin egen alvorlige sykdom og død ble til stor trøst for oss.

Vår lille doktorklubb er blitt fattigere. Vi vil savne vår vakre, kloke, livsglade og omsorgsfulle venninne.

Våre tanker går nå til barna Pål og Katja og barnebarna Emil, Alexandra, Katinka og Oscar som har mistet en flott mor, farmor og mormor.

Publisert: 28. januar 2019. Tidsskr Nor Legeforen. DOI: 10.4045/tidsskr.18.0902

(C) Tidsskrift for Den norske legeforening 2020. Lastet ned fra tidsskriftet.no 